\title{
Everybody is different: A plea for individualizing treatment of aortopathy
}

\author{
Hans-Hinrich Sievers, MD
}

\footnotetext{
From the Department of Cardiac and Thoracic Vascular Surgery, University Medical Center Schleswig-Holstein, Campus Lübeck, Lübeck, Germany.

Disclosures: Author receives royalties for sinus prosthesis and curved arch prosthesis from B. Braun Melsungen AG, Melsungen, Germany.

Received for publication Oct 31, 2017; accepted for publication Nov 9, 2017; available ahead of print Dec 6, 2017.

Address for reprints: Hans-Hinrich Sievers, MD, Department of Cardiac and Thoracic Vascular Surgery, University Medical Center Schleswig-Holstein, Ratzeburger Allee 160, Lübeck 23538, Germany (E-mail: Hans-Hinrich.Sievers@uksh.de).

J Thorac Cardiovasc Surg 2018;156:481-2

0022-5223/ $\$ 36.00$

Copyright $(2017$ by The American Association for Thoracic Surgery

https://doi.org/10.1016/j.jtcvs.2017.11.024
}

The gods did not reveal, from the beginning,

All things to us, but in the course of time

Through seeking we may learn and know things better.

But as for certain truth, no man has known it,

Nor shall he know it, neither of the gods

Nor yet of all the things of which I speak.

For even if by chance he were to utter

The final truth, he would himself not know it:

For all is but a woven web of guesses.

$$
\text { -Xenophanes (c 570-475 BCE) }
$$

Everybody is genetically different living in a different environment - the rhythm of life. The resulting phenotype, such as aortopathy in patients with a bicuspid aortic valve, is unique, calling for individual treatment. ${ }^{1}$ To find the optimal treatment or final truth would require performing competing procedures in the same patients at the same time. This is impossible, ergo we cannot find the final truth. ${ }^{2}$ The next hope lies in randomized trials; however, these are not available, so we are left with knowledge from observational studies. Borger and colleagues ${ }^{3}$ are to be congratulated for the great efforts in condensing the best available knowledge and evidence in the executive summary of the American Association for Thoracic Surgery guidelines on bicuspid aortic valve-related aortopathy presented in this issue of the Journal, giving us clinicians a welcome background, a guide as well as a safe feeling of general decision making.

The guidelines, however, are based mainly on an absolute diameter, leaving some kind of uncertainty for the individual patient, which is newly inflamed by reporting that dissection has occurred at a mean diameter of $40.1 \mathrm{~mm}$, which is lower than assumed. ${ }^{4}$ This is in part related to the fact that the aortic wall ruptures when the wall stress exceeds the tensile strength of the tissue (safe knowledge), whereby wall stress is related not only the diameter but also to the pressure and the quality of wall tissue (Law of Laplace). For wall stress calculation, the doubling of

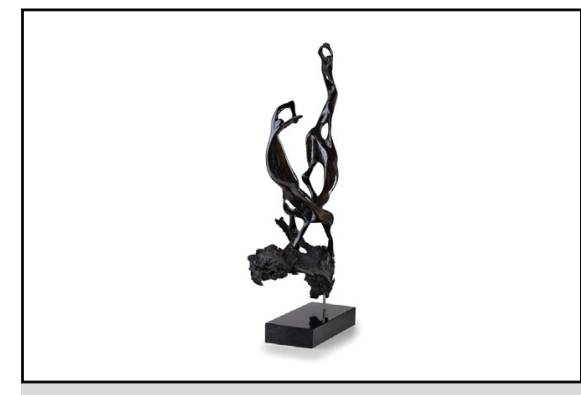

Two different individuals dancing the rhythm of life sculpted in bog oak by the author.

\section{Central Message}

Current aortopathy guidelines in bicuspid aortic valve are a solid basis for general decision making; evolution needs iteration of knowledge for individualization to approach the optimal treatment.

See Article page 473. pressure, which is possible during exercise or emotional stress, is the same as doubling the diameter, indicating that blood pressure is a real enemy that can change instantaneously and unpredictably. Normally, this is uneventful; in patients with bicuspid aortic valve, however, the quality of the wall tissue in inferior to normal, resulting in a higher incidence of dissection than in the general population. ${ }^{5}$ This situation is not fully satisfying, calling for improving guidelines by identifying and integrating new risk factors. Some new factors are emerging, such as aortic regurgitation, growth of aorta, aortic wall thickness, family history, and phenotype complex. These are already listed in the executive summary, providing a gentle hint for a more individual approach. However, how do the age, body surface area, and sex relate to the diameter? A 41-mm diameter in a $1.6-\mathrm{m}^{2}$ body surface area woman at 21 years of age, which is more than $50 \%$ larger than normal and by definition an aneurysm, is more pathologic than a $41-\mathrm{mm}$ diameter in a $2.2 \mathrm{~m}^{2}$ body surface area man at 70 years of age. ${ }^{6}$ These aspects need further evaluation to approach individualized treatment (Figure 1). ${ }^{7,8}$ By the way, do we know whether aortopathy is related to nutrition, such as occurs in bees, in which the phenotype is changed by nutrition-induced methylation, ${ }^{9}$ and might it become possible to normalize aortic wall tissue by gene manipulation or drugs ${ }^{10}$ ? 


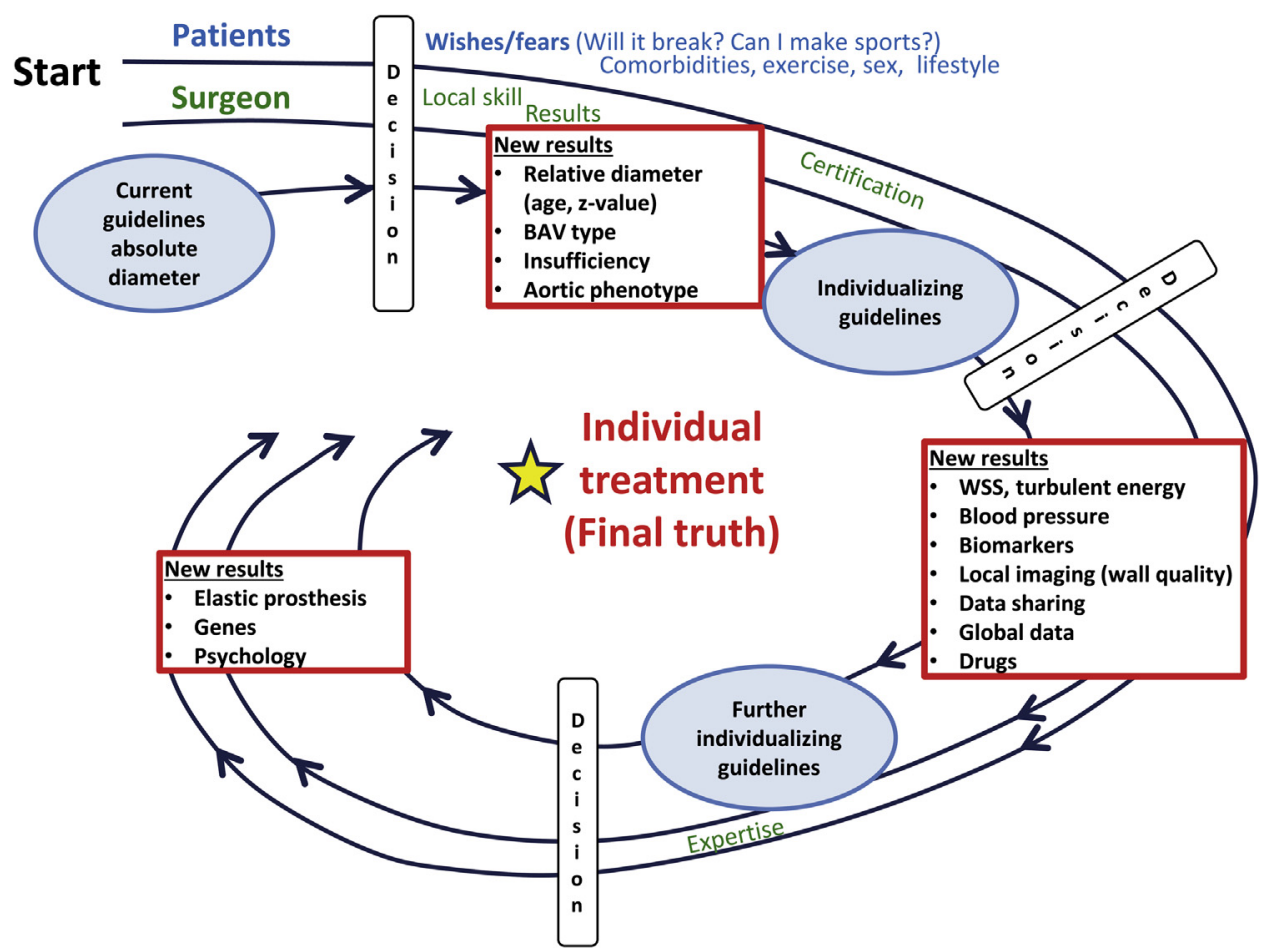

FIGURE 1. Iterative accumulation of knowledge to approach individual treatment of bicuspid valve aortopathy. BAV, Bicuspid aortic valve; WSS, wall shear stress.

On the other hand, we as surgeons should increase all efforts to reduce the risk of replacing the ascending aorta to near zero and develop compliant material to imitate the Windkessel function. Recently, I listened to the following conversation: "Dad, I need surgery on my leaking bicuspid aortic valve, and my ascending aorta has already grown to $41 \mathrm{~mm}$ in diameter, which is much larger than normal. I am 21 years of age and small and want to live for 60 years more without fear of dissection and exerting full exercise. Shall I ask the surgeon to concomitantly replace the aorta? Dad, you are a cardiac surgeon, please advise. Didn't Uncle Joe die of dissection?" Efforts to approach the optimal individual treatment need change and evolution of guidelines, with all sophisticated methods used to reach best evidence and handling trial and risk of error in the ever web of critical guesswork, a net of hypotheses and assumptions leading to some kind of Popperian modesty. ${ }^{2}$

\section{References}

1. Sievers HH, Sievers HL. Aortopathy in bicuspid aortic valve disease-genes or hemodynamics? or Scylla and Charybdis? Eur J Cardiothorac Surg. 2011;39:803-4.
2. Popper KR. The Logic of Scientific Discovery. New York: Basic Books; 1959.

3. Borger MA, Fedak PW, Stephens EH, Gleason TG, Girdauskas E, Ikonomidis J, et al. American Association for Thoracic Surgery guidelines on bicuspid aortic valve-related aortopathy: executive summary. J Thorac Cardiovasc Surg. 2018; 156:473-80.

4. Rylski B, Blanke P, Beyersdorf F, Desai ND, Milewski RK, Siepe M, et al. How does the ascending aorta geometry change when it dissects? J Am Coll Cardiol. 2014;63:1311-9.

5. Michelena HI, Prakash SK, Della Corte A, Bissell MM, Anavekar N, Mathieu P, et al; BAVCon Investigators. Bicuspid aortic valve: identifying knowledge gaps and rising to the challenge from the International Bicuspid Aortic Valve Consortium (BAVCon). Circulation. 2014;129:2691-704.

6. Sievers HH, Charitos EI. Ascending aorta diameters: normal, abnormal, or pathologic? Ann Thorac Surg. 2016;101:2430-1.

7. Sievers HH, Stierle U, Mohamed SA, Hanke T, Richardt D, Schmidtke C, et al. Toward individualized management of the ascending aorta in bicuspid aortic valve surgery: the role of valve phenotype in 1362 patients. J Thorac Cardiovasc Surg. 2014;148:2072-80.

8. Sievers HH, Stock S, Stierle U, Klotz S, Charitos EI, Diwoky M, et al. Longerterm results, $\mathrm{z}$ scores, and decision nomograms for treatment of the ascending aorta in 1693 bicuspid aortic valve operations. J Thorac Cardiovasc Surg. 2018;156:549-59.e2.

9. Lyko F, Foret S, Kucharski R, Wolf S, Falckenhayn C, Maleszka R. The honey bee epigenomes: differential methylation of brain DNA in queens and workers. PLoS Biol. 2010;8:e1000506.

10. Shalem O, Sanjana NE, Zhang F. High-throughput functional genomics using CRISPR-Cas9. Nat Rev Genet. 2015;16:299-311. 